\title{
Effects of seaweed extract on the growth, yield and quality of cherry tomato under different growth conditions
}

\author{
Senad MURTIC ${ }^{1, *}$, Rodoljub OLJACA ${ }^{2}$, Mirela SMAJIC MURTIC ${ }^{3}$, Amila VRANAC $^{3}$, Ivana KOLESKA ${ }^{4}$, Lutvija $^{5}$ \\ KARIC $^{5}$
}

Received November 21, 2017; accepted June 15, 2018.

Delo je prispelo 21. novembra 2017, sprejeto 15. junija 2018.

\begin{abstract}
An experiment was carried out to determine the effect of foliar application of seaweed extract $(0.2 \%)$ on the growth, yield and quality of cherry tomato under stress and non-stress conditions. The greenhouse experiment was set up in a randomized block design with four treatments in three replications. Treatments were as follows: $\mathrm{V}_{1}$ - seedlings treated by seaweed extract and subjected to drought; $\mathrm{V}_{2}$ seedlings treated by seaweed extract and regularly watered; $V_{3}$ - non-treated seedlings subjected to drought; $\mathrm{V}_{4}$ - non-treated seedlings regularly watered. Cherry tomato seedlings treated by seaweed extract had a lower content of proline and higher leaf water potential compared to non-treated seedlings under stress conditions, indicating that application of this fertilizer contributes to better adaptation of cherry tomato seedlings to stress. Treatment with seaweed extract also positively influenced the yield and quality of cherry tomato (total soluble solids, vitamin $\mathrm{C}$, lycopene) under both standard and drought stress conditions as compared to untreated plants in same conditions. Positive effects of seaweed extract on growth and quality of cherry tomato are result of its specific composition, as well as ability of cherry tomato plants to utilize bioactive substances in seaweed extracts for its growth and development.
\end{abstract}

Key words: cherry tomato; seaweed extract; osmotic adjustment; photosynthesis; antioxidants; growth conditions

\section{IZVLEČEK}

\section{UČINKI IZVLEČKOV MORSKIH ALG NA RAST, PRIDELEK IN KAKOVOST ČEŠNJEVEGA PARADIŽNIKA V RAZLIČNIH RASTNIH RAZMERAH}

Izveden je bil poskus za določanje učinkov foliarnega gnojenja $\mathrm{z}$ izvlečkom morskih alg $(0,2 \%)$ na rast, pridelek in kakovost češnjevega paradižnika $\mathrm{v}$ stresnih in nestresnih razmerah. V rastlinjaku je bil postavljen naključni bločni poskus $s$ štirimi obravnavanji in tremi ponovitvami. Obravnavanja so bila: $\mathrm{V}_{1}$ - tretma sadik $\mathrm{z}$ izvlečkom morskih alg in izpostavitev suši; $\mathrm{V}_{2}$ - tretma sadik $\mathrm{z}$ izvlečkom morskih alg in redno zalivanje; $V_{3}-$ netretirane sadike so bile izpostavljene suši; $\mathrm{V}_{4}$ - netretirane sadike so bile redno zalivane. Sadike češnjevca, ki so bile tretirane z izvlečkom morskih alg, so imele manjšo vsebnost prolina in večji vodni potencial listov $\mathrm{v}$ primerjavi $\mathrm{z}$ netretiranimi $\mathrm{v}$ stresnih razmerah, kar kaže, da je uporaba tega gnojila prispevala $\mathrm{k}$ boljši prilagoditvi sadik na stres. Foliarno gnojenje $\mathrm{z}$ izvlečekom morskih alg je tudi pozitivno vplivalo na pridelek in kakovost češnjevca (celokupno vsebnost topnih snovi, vitamina $\mathrm{C}$, likopena) $\mathrm{v}$ kontroli in stresnih razmerah $\mathrm{v}$ primerjavi $\mathrm{Z}$ netretiranimi rastlinami $\mathrm{v}$ enakih razmerah. Pozitivni učinki izvlečka morskih alg na rast in kakovost češnjevca so posledica njegove specifične sestave kot tudi sposobnosti tega paradižnika, da bioaktivne snovi iz izvlečkov morskih alg uporabi za rast in razvoj.

Ključne besede: češnjev paradižnik; izvleček morskih alg; osmotsko uravnavanje; fotosinteza; antioksidanti; rastne razmere

\footnotetext{
1 University of Sarajevo, Faculty of Agriculture and Food Sciences, Department of Plant Physiology, Zmaja od Bosne 8, 71 000 Sarajevo, Bosnia and Hezegovina, *corresponding author: murticsenad@ hotmail.com

2 University of Banja Luka, Faculty of Agriculture, Department of Soil Science, Physiology and Plant Nutrition, Bulevar vojvode Petra Bojovića 1A, 78000 Banja Luka, Bosnia and Herzegovina

3 University of Sarajevo, Faculty of Agriculture and Food Sciences, Department of Food Technology, Zmaja od Bosne 8, 71000 Sarajevo, Bosnia and Herzegovina

4 University of Banja Luka, Faculty of Agriculture, Department of Soil Science, Physiology and Plant Nutrition, Bulevar vojvode Petra Bojovića 1A, 78000 Banja Luka, Bosnia and Herzegovina

5 University of Sarajevo, Faculty of Agriculture and Food Sciences, Department of Vegetable Crops, Zmaja od Bosne 8, 71000 Sarajevo, Bosnia and Herzegovina
} 


\section{INTRODUCTION}

Water stress caused by drought induces morphology, biochemistry and physiology changes in plant, leading to considerable reductions in plant growth and productivity (Atkinson and Urwin, 2012; Li and Mattson, 2015). Besides, drought stress is able to promote reactive oxygen species (ROS) production which in turn leads to damage of all cellular components primarily proteins, lipids and nucleic acids (Ali and Anjum, 2016; Ali et al., 2016).

Plants possess a number of defense mechanisms to cope with stress and some of the more important are osmotic adjustment and efficient antioxidant systems. The osmotic adjustment is indicated by the accumulation of proline, glycine betaine and other metabolites the structural capabilities to maintain homeostasis and improve plant functioning under drought stress (Hayat et al., 2012). The ability of plants to improve their defense mechanism against stress also depends on the possibility of plant to produce secondary metabolites with strong antioxidant activity, among them phenolic compounds (Sanchez-Rodriguez et al., 2011).

Tomatoes are very sensitive to drought (Nuruddin et al., 2003). There are currently several approaches that potentially reduce the impact of drought stress on vegetable cultivation, such as development of drought stress tolerant cultivars, adopting agronomic practices, efficient irrigation systems and use organic fertilizers that can contribute to mitigate drought stress (Tilman et al., 2002; Mikiciuk and Dobromilska, 2014). Application of seaweed extract also might contribute to the strengthening of the plant defense system against stress since the seaweed extracts are very rich in bioactive compounds, including betaine, proline, and aromatic amino acids (Arioli et al., 2015). Currently, many types of seaweed extracts can be purchased for commercial agriculture, especially for vegetable cultivation (Craigie, 2011). Bio-algeen S-92 (Shulze \& Hermsen $\mathrm{GmbH}$, Germany) is an organic fertilizer for foliar supplemental feeding, derived from seaweed Ascophyllum nodosum (L.) Le Jol. According to the product specification Bio-algeen S-92 contains $96 \%$ water, $0.02 \% \mathrm{~N}, 0.006 \% \mathrm{P}, 0.096 \% \mathrm{~K}, 0.31 \% \mathrm{Ca}$, $6.3 \mathrm{mg} \mathrm{l}^{-1} \mathrm{Fe}, 1 \mathrm{mg} \mathrm{l}^{-1} \mathrm{Zn}, 0.6 \mathrm{mg} \mathrm{l}^{-1} \mathrm{Mn}$, vitamins $\left(\mathrm{B}_{1}\right.$, $\mathrm{B}_{3}, \mathrm{~B}_{6}, \mathrm{~B}_{9}$ and vitamin E), a certain amount of essential amino acids: alanine, glycine, tryptophan, histidine, proline, glutamine and other active natural substances such as organic acids and microelements that provide lots of benefits for plant growth and development (Dobromilska et al., 2008). As far as we know, the possible application of this preparation in greenhouse production of cherry tomato has not been tested so far, especially under drought stress conditions.

Cherry tomato was selected as the subject of this study, particularly because this species is commonly affected by a lack of moisture, and also because this vegetable an important part of a healthy diet.

\section{MATERIALS AND METHODS}

\subsection{Field experiment}

The study was carried out in 2015 under controlled conditions, in the greenhouse of public communal company 'Park' in Sarajevo. In the experiment air temperature in greenhouse was maintained at 23 to $25^{\circ} \mathrm{C}$ during day and 20 to $22{ }^{\circ} \mathrm{C}$ at night. Relative humidity (RH) was maintained between $60 \%$ and $70 \%$, with combined venting to reduce RH, and with highpressure fogging to increase RH. During warm days shade cloth over the top of a greenhouse was used to reduce solar radiation entry.

The first part of the study involved transplanting of cherry tomato seedlings into individual pots $(20 \mathrm{~cm}$ diameter $\times 13 \mathrm{~cm}$ height), containing substrate Florahum-SP (8 April 2015). Cherry tomato seedlings used in the experiment were produced at a certified nursery located near the greenhouse and showed no significant difference in terms of size and appearance. The substrate used in this study represented a mixture of white and black peat enriched with nutritional supplements. The main chemical characteristics of substrate were as follows: $\mathrm{pH} 5.5-6.5$, EC $1.2-1.8 \mathrm{mS}$ $\mathrm{cm}^{-1}$, content of N $140-180 \mathrm{mg} \mathrm{l}^{-1}$, content of $\mathrm{P}_{2} \mathrm{O}_{5} 160$ - $300 \mathrm{mg} \mathrm{l}^{-1}$, and content of $\mathrm{K}_{2} \mathrm{O} 180-400 \mathrm{mg} \mathrm{l}^{-1}$.

The second part of the study related to setting up an experiment in which the cherry tomato seedlings were treated by $0.2 \%$ solution of Bio-algeen S92, extract from Ascophyllum nodosum (ANE). The experimental trial was set up in a randomized block design with four treatments in three replications. Each of these treatments was present with sixty seedlings. The treatments were as follows:

$\mathrm{V}_{1}$ - double foliar treatment with ANE (100 ml per plant) before exposure to drought stress,

$\mathrm{V}_{2}$ - double foliar treatment with ANE $(100 \mathrm{ml}$ per plant) and regularly watered (non-stressed), 
$\mathrm{V}_{3}$ - without ANE treatment before exposure to drought stress,

$\mathrm{V}_{4}$ - without ANE treatment and regularly watered (nonstressed).

ANE application was carried out manually, using small bottles with sprayers. The first ANE application was done immediately after the transplanting of seedlings ( 8 April 2015), and the second fifteen days later. Five days after the second treatment, the cherry tomato seedlings $\left(V_{1}\right.$ and $\left.V_{3}\right)$ were exposed to drought stress conditions (non-watering), while the other cherry tomato seedlings $\left(\mathrm{V}_{2}\right.$ and $\left.\mathrm{V}_{4}\right)$ were not exposed to drought stress, that is, they were regularly watered.

Exposure of cherry tomato seedlings to drought stress conditions lasted until the moment in which first visually observable effects of drought appeared on the seedlings as wilting leaves. This moment was also represented the beginning of the third part of study, which included measurement of selected physiological parameters for evaluating of drought tolerance in cherry tomato seedlings: leaf water potential, leaf area, photosynthetic pigments, content of proline, total phenolic and flavonoid content, and total antioxidant capacity. Leaf water potential was estimated by the dye method (Knipling, 1967), content of proline was measured by acid-ninhydrin method (Bates et al., 1973), photosynthetic pigments were extracted with $80 \%$ acetone (Wettstein, 1957) and the total amount of pigments were determined with equations recommended by Lichtenthaler and Wellburn (1983), leaf area was measured by millimeter graph paper method (Pandey and Singh, 2011), total phenolic content was estimated using Folin Ciocalteu method (Ough and Amerine, 1988), total flavonoids according to Aluminium chloride colorimetric assay (Zhishen et al., 1999), and the ferric reducing/antioxidant power (FRAP) assay was used to determine total antioxidant capacity (Benzie and Strain, 1996).

The next part of study involved the cultivation of cherry tomato under standard growth conditions in all variants until the time of technological maturity of fruits, in order to test how the exposure of seedlings to drought stress and application of ANE affect the yield and quality of fruit. Fruit nutritional quality was analyzed by detecting the following parameters: total soluble solids, titratable acidity, lycopene, vitamin $\mathrm{C}$, total phenolic and flavonoid content, content of rutin and naringenin, and total antioxidant capacity of cherry tomato fruits. Estimation of total soluble solids was performed by digital refractometer according to the International standard method (ISO 2173, 2003), titratable acidity was estimated by titration with $\mathrm{NaOH}$ according to AOAC Official method No. 942.15 (AOAC, 2000) and vitamin $\mathrm{C}$ by titration with $2,6-$ dichlorophenolindophenol according to AOAC Official method No. 967.21 (AOAC, 2006).

\subsection{Estimation of proline}

Estimation of proline was carried out as follows: $1 \mathrm{~g}$ of fresh leaf samples was homogenized in $3 \%(w / v)$ aqueous 5-sulfosalicylic acid and the homogenate was filtered through a glass-fiber filter to a plastic test tube. $2 \mathrm{ml}$ of filtrate was mixed with $2 \mathrm{ml}$ of ninhydrin reagent and $2 \mathrm{ml}$ of glacial acetic acid in a test tube and boiled for 1 hour at $100{ }^{\circ} \mathrm{C}$ (ninhydrin reagent was prepared as follows: $2.5 \mathrm{~g}$ of ninhydrin was dissolved in a mixture of $60 \mathrm{ml}$ glacial acetic acid and $40 \mathrm{ml} 6 \mathrm{~mol} \mathrm{l}^{-}$ ${ }^{1}$ phosphoric acid). After termination of reaction in ice bath, the reaction mixture was extracted with $4 \mathrm{ml}$ of toluene, and mixed vigorously with a vortex mixer for 15 - $20 \mathrm{sec}$. The reddish layer of mixture was transferred to cuvette and absorbance read at $520 \mathrm{~nm}$ with a UV/Vis spectrophotometer (Thermo Scientific, Madison, USA) using toluene as blank. The proline concentration was determined from a standard curve $(0$ $5 \mu \mathrm{g} \mathrm{ml}^{-1}$ ) and then the values were recalculated on fresh mass $\left(\mu \mathrm{g} \mathrm{g}^{-1} \mathrm{FM}\right)$.

\subsection{Estimation of photosynthetic pigments}

Extraction of pigments was made from $200 \mathrm{mg}$ of fresh leaves in acetone $(80 \%)$ and absorbance of extract was read spectrophotometrically at $662 \mathrm{~nm}, 645 \mathrm{~nm}$, and $470 \mathrm{~nm}$. The total amounts of pigments were determined with equations recommended by Lichtenthaler and Wellburn (1983) as follows:

Chlorophyll $a=11.75 \mathrm{~A}_{662}-2.350 \mathrm{~A}_{645}$

Chlorophyll $b=18.61 \mathrm{~A}_{645}-3.960 \mathrm{~A}_{662}$

Carotenoids $=1000 \mathrm{~A}_{470}-2.270 \mathrm{Chl} a-81.4 \mathrm{Chl} b / 227$

The results were expressed as $\mathrm{mg}$ of pigment per $\mathrm{g}$ of fresh mass ( $\left.\mathrm{mg} \mathrm{g}^{-1} \mathrm{FM}\right)$.

\subsection{Extraction of the plant material}

Extraction of phenolic compounds from dry leaves and fruits of cherry tomato was performed in reaction flasks using a $30 \%$ aqueous solution of ethanol. The flasks were boiled at $60{ }^{0} \mathrm{C}$ for 1 hour using a reflux condenser. Extracts thus obtained were used for the estimation of the total content of phenolic and flavonoids, and total antioxidant capacity.

\subsection{Estimation of total phenolic content}

The total phenolic content of the extract was determined as follows: $0.25 \mathrm{ml}$ of extract, $15 \mathrm{ml}$ of distilled water, and $1.25 \mathrm{ml}$ of Folin-Ciocalteu's reagent (diluted by distilled water in the ratio 1:2) was mixed into $25 \mathrm{ml}$ flask. The mixture was incubated at room temperature for $15 \mathrm{~min}$ and then $3.75 \mathrm{ml}$ saturated sodium carbonate solution was added. Flask was filled to the mark with $30 \%$ ethanol and heated in water bath at $50{ }^{\circ} \mathrm{C}$, for 30 
min. After cooling to room temperature absorbance was measured at $765 \mathrm{~nm}$. The total phenolic content was calculated using a standard curve with gallic acid (0 $500 \mathrm{mg} \mathrm{l}^{-1}$ ), and results were expressed as $\mathrm{mg}$ of gallic acid equivalent per $\mathrm{g}$ dry mass (mg eq. $\mathrm{GA} \mathrm{g}^{-1} \mathrm{DM}$ ).

\subsection{Estimation of total flavonoids content}

The total flavonoid content of the extract was determined by the aluminium chloride colorimetric assay as follows: $1 \mathrm{ml}$ of extract was added to $10 \mathrm{ml}$ volumetric flask containing $4 \mathrm{ml}$ of distilled water and $0.3 \mathrm{ml} 5 \% \mathrm{NaNO}_{2}$. After $5 \mathrm{~min} .0 .3 \mathrm{ml} 10 \% \mathrm{AlCl}_{3}$ was added, and the mixture was incubated at room temperature for $6 \mathrm{~min}$. Then $2 \mathrm{ml}$ of $1 \mathrm{~mol} \mathrm{l}^{-1} \mathrm{NaOH}$ was added and the flask was made up to $10 \mathrm{ml}$ with distilled water. The flask was incubated at room temperature for $15 \mathrm{~min}$, and absorbance was read at $510 \mathrm{~nm}$. The total flavonoid content was calculated using a standard curve with catechin $\left(0-100 \mathrm{mg} \mathrm{l}^{-1}\right)$ end results were expressed as $\mathrm{mg}$ of catechin equivalent per $\mathrm{g}$ of dry mass (mg eq. $\mathrm{C} \mathrm{g}^{-1} \mathrm{DM}$ ).

\subsection{Estimation of total antioxidant capacity}

The total antioxidant capacity of the extract was determined by ferric reducing antioxidant power (FRAP) assay as follows: $240 \mu \mathrm{l}$ of distilled water, $80 \mu \mathrm{l}$ of extract, and $2080 \mu \mathrm{l}$ of FRAP reagent (reagent was obtained by mixing $0.3 \mathrm{~mol} \mathrm{l}^{-1}$ acetate buffer $(\mathrm{pH}=3.6)$, $10 \mathrm{mmol}^{-1}$ TPTZ (2,4,6-tripyridyl-s-triazine) and $20 \mathrm{mmol} \mathrm{l}^{-1} \mathrm{FeCl}_{3} \times 6 \mathrm{H}_{2} \mathrm{O}$ in ratio $\left.10: 1: 1\right)$ were added into a $10 \mathrm{ml}$ Erlenmeyer flask and heated in water bath at $37{ }^{\circ} \mathrm{C}$, for $5 \mathrm{~min}$ and the absorbance was measured at $595 \mathrm{~nm}$. The values of total antioxidant capacity were calculated using a standard curve with $\mathrm{FeSO}_{4} \times 7 \mathrm{H}_{2} \mathrm{O}\left(0-2000 \mu \mathrm{mol} 1^{-1}\right)$ and results were expressed as $\mu \mathrm{mol} \mathrm{Fe}^{2+}$ per $\mathrm{g}$ of dry mass of extract $\left(\mu \mathrm{mol} \mathrm{Fe}{ }^{2+} \mathrm{g}^{-1} \mathrm{DM}\right)$.

\subsection{Estimation of lycopene}

Lycopene content was determined according to method of Davis et al. (2003) as follows: Approximately 0.3 to $0.6 \mathrm{~g}$ of the homogenized samples of cherry tomato fruits were weighed in Erlenmeyer flasks and $5 \mathrm{ml}$ of $0.05 \% \quad(\mathrm{w} / \mathrm{v})$ butylated hydroxytoluene (BHT) in acetone, $5 \mathrm{ml}$ of ethanol and $10 \mathrm{ml}$ of hexane were added. Samples were extracted on an orbital shaker for $15 \mathrm{~min}$ on ice. After shaking, $3 \mathrm{ml}$ of deionized water were added to each flask and the samples were shaken for an additional $5 \mathrm{~min}$ on ice. Samples were then left at room temperature for $5 \mathrm{~min}$ to allow the separation of both phases. The absorbance of the upper layer was measured in a 1-cm-path-length quartz cuvette at $503 \mathrm{~nm}$ blanked with hexane, and results were expressed as mg lycopene per $\mathrm{g}$ of fresh mass $\left(\mu \mathrm{g} \mathrm{g}{ }^{-1}\right.$ FM).

\subsection{Individual flavonoid compounds extraction and analysis}

The extraction of samples $(5 \mathrm{~g})$ was made in $10 \mathrm{ml}$ of extracted solution (methanol $+3 \%$ formic acid $+1 \%$ $\mathrm{m} / \mathrm{v}$ 2,6-di-tert-butyl-4-methyilphenol/BHT) according to Escarpa and Gonzales (2000).

Individual flavonoid compounds (naringenin and rutin) were analyzed by using Thermo Scientific Finnigan Surveyor HPLC-DAD system, controlled by a ChromQuest 4.0 chromatography workstation software system (Thermo Scientific, San Jose, CA, USA). Separation of flavonoid compounds was achieved by using Pursuit XRs 3 C-18 column $(4.6 \times 150$ mm, $5 \mu \mathrm{m}$; Agilent Technologies, Santa Clara, CA, USA) operated at $25{ }^{\circ} \mathrm{C}$. The mobile phase consisted of the following linear gradient: $97 \%$ acetonitrile $+3 \%$ redistilled water $+0.1 \%$ formic acid (A) and $97 \%$ redistilled water + $3 \%$ acetonitrile $+0.1 \%$ formic acid (B). Sample injection volume was $20 \mu \mathrm{L}$ and the flow rate was $0.6 \mathrm{ml} \mathrm{min}^{-1}$. The sample was eluted in accordance with method described by Marks et al. (2007). Detection of flavonoid compounds was performed with a diode array detector (DAD) at 280 and $350 \mathrm{~nm}$. Naringenin and rutin were identified on the basis of their retention times and addition of external standards and quantification was made according to concentrations of corresponding external standard and expressed as $\mathrm{mg}$ per $100 \mathrm{~g}$ of fresh mass (mg $\left.100 \mathrm{~g}^{-1} \mathrm{FM}\right)$.

\subsection{Statistic data processing}

All experimental measurements were carried out in triplicate and the results were expressed as mean \pm standard deviation. The data obtained were processed by application of standard statistic methods of variance analysis (ANOVA) using Microsoft Excel 2013 software program, and the significant differences between the variants were determined using Least Significant Differences at 0.05 level of probability $\left(\mathrm{LSD}_{0.05}\right)$.

\section{RESULTS AND DISCUSSION}

\subsection{Leaf water potential}

Exposure of cherry tomato seedlings to drought stress caused a decrease in leaf water potential $(\Psi)$ as compared with control (non-stressed seedlings), regardless of ANE treatment, and as expected, with the progression of the stress, plant water potential 
decreased. However, the reduction of $\Psi$ being less pronounced for stressed plant treated by ANE (Figure
1), suggesting that this treatment helps the maintain homeostasis in plant cells under stress conditions.
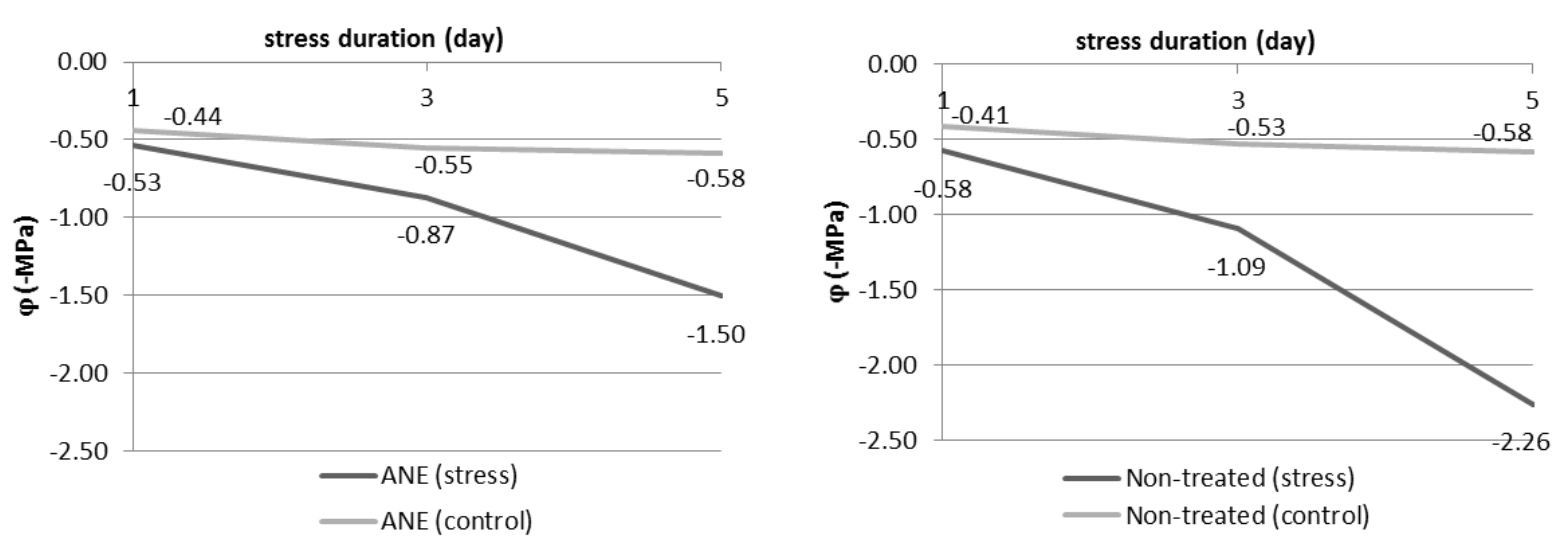

Figure 1: Leaf water potential (-MPa) depending on treatment with ANE and exposure to water stress

Numerous studies have also found that ANE application contributes to better osmotic adjustment of plants to stress (Khan et al., 2009; Ha et al., 2014). Karabudak et al. (2014) reported that substances such as glycine betaine and sterols present in ANE act as a buffer against major osmotic changes in plant cells and thus reduces negative effects of stress on plants. In addition, ANE contain many other osmolytes including amino acids: proline, valine, isoleucine and aspartic acid, vitamins and microelements and numerous other active natural substances that improve the stress tolerance of agricultural crops (Spann and Little, 2011).

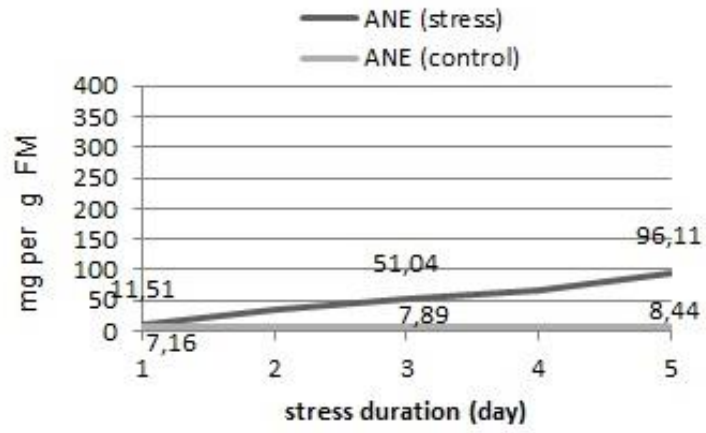

Figure 3: Proline content $\left(\mu \mathrm{g} \mathrm{g}^{-1} \mathrm{FM}\right)$ depending on the ANE treatment and exposure to water stress

Since the faster increase of proline content in leaves indicates plant stress, the results of the present study suggest that application of ANE contributes to a better osmotic adjustment of cherry tomato seedlings to stress conditions. Extracts from seaweed have also been reported to reduce drought stress in cultivation of

\subsection{Proline content}

The results of the proline estimation indicated an increase of the proline level in leaves of all cherry tomato seedlings exposed to drought stress conditions. Furthermore, in experiment variant where cherry tomato seedlings were treated by ANE, the increase of proline in leaves during drought stress was much lower compared with non-treated seedlings grown under same conditions (Figure 2).

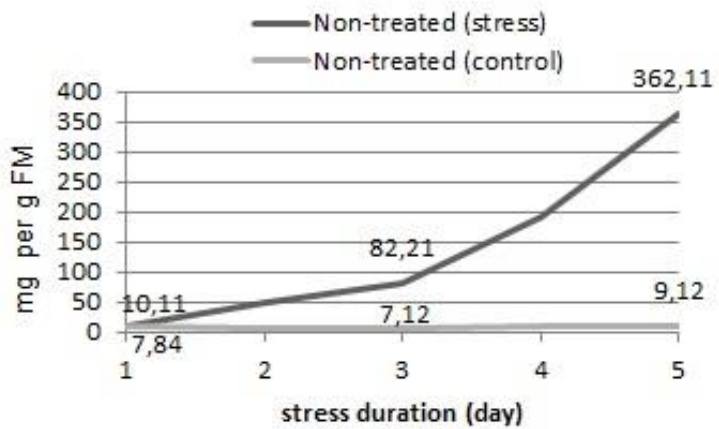

vegetable, ornamental crops and grasses (Zhang and Ervin, 2004; Neily et al., 2010).

\subsection{Photosynthetic pigments and leaf area}

The results of the analysis of photosynthetic pigments showed that the content of chlorophyll $a$ (Chl $a$ ), chlorophyll $b(\mathrm{Chl} b)$ and carotenoids in leaves of 
cherry tomato seedlings were decreased under drought stress conditions, regardless of ANE treatment (Table 1). This decrease was statistically significant for pigment $\mathrm{Chl} a$, while for pigment $\mathrm{Chl} b$ and carotenoids were not. Numerous studies have also found that plant reduces the content of pigments in leaves under stress conditions (Ghorbanli et al., 2013; Yuan et al., 2016). Jaleel et al. (2009) reported that reducing the photosynthetic pigments content in leaves may be the result of the impairment in pigment biosynthesis or destruction of pigments due to disturbing in uptake of nutrients under drought stress conditions. Anjum et al. (2011) found that drought causes not only the reduction of the photosynthetic pigments content but it also leads to the destructive changes in the chloroplast, resulting in decreased photosynthetic capacity of plant.

The research results also indicate that ANE application contributes to higher synthesis of photosynthetic pigments in cherry tomato leaves and thus improving plant survival under subsequent stress. González et al. (2013) reported that the efficiency of seaweed extracts application to increase the content of pigments has been mainly attributed to large number of natural nitrogenous compounds present in seaweed which are important for the synthesis of chlorophyll pigments.

Table 1: Photosynthetic pigments content and leaf area of cherry tomato seedlings

\begin{tabular}{lcccc}
\hline Treatment & $\begin{array}{c}\mathrm{Chl} a \\
\left(\mathrm{mg} \mathrm{g}^{-1} \mathrm{FM}\right)\end{array}$ & $\begin{array}{c}\mathrm{Chl} b \\
\left(\mathrm{mg} \mathrm{g}^{-1} \mathrm{FM}\right)\end{array}$ & $\begin{array}{c}\text { Carotenoids } \\
\left(\mathrm{mg} \mathrm{g}^{-1} \mathrm{FM}\right)\end{array}$ & $\begin{array}{c}\text { Leaf area } \\
\left(\mathrm{cm}^{2}\right)\end{array}$ \\
\hline $\mathrm{V}_{1}$ ANE (stress) & $1.36 \pm 0.12^{\mathrm{bc}}$ & $0.46 \pm 0.03$ & $0.45 \pm 0.01$ & $16.06 \pm 3.01^{\mathrm{bc}}$ \\
\hline $\mathrm{V}_{2}$ ANE (non-stress) & $1.51 \pm 0.07^{\mathrm{a}}$ & $0.51 \pm 0.10$ & $0.53 \pm 0.11$ & $19.86 \pm 5.88^{\mathrm{a}}$ \\
\hline $\mathrm{V}_{3}$ Non-treated (stress) & $1.13 \pm 0.11^{\mathrm{d}}$ & $0.45 \pm 0.05$ & $0.46 \pm 0.05$ & $13.21 \pm 2.95^{\mathrm{d}}$ \\
\hline $\mathrm{V}_{4}$ Non-treated (non-stress) & $1.38 \pm 0.04^{\mathrm{b}}$ & $0.47 \pm 0,05$ & $0.47 \pm 0.05$ & $17.84 \pm 3.54^{\mathrm{b}}$ \\
\hline $\mathrm{LSD}_{0.05}$ & 0.095 & - & - & 2.186 \\
\hline
\end{tabular}

Values expressed as main \pm standard deviation.

Different letters in each column represent significant difference among variants at 0.05 level of probability

As shown in Table 1, leaf area in stressed cherry tomato seedlings were lower than in treatments where the seedlings were regularly watered. Many studies have shown the similar results about the effect of drought stress on leaf area (Jureková et al., 2011; Aldana et al., 2014). Galmés et al. (2013) reported that reducing the leaf area of plant under stress conditions is primarily result of reduction of cell enlargement and limited cell division due to lack of water.

The present data also showed that in stressful conditions, cherry tomato seedlings treated by ANE had a higher leaf area compared to untreated plants. This data indicates that the treated plants were less stressed, supporting the hypothesis that the application of ANE postpones and thus reduces negative effects of drought on cherry tomato seedlings.

3.4 Total phenolic, total flavonoid content, and antioxidant capacity of leaf extracts

A secondary effect of drought stress on plants is the increased of reactive oxigen species (ROS) such as superoxide radicals $\left(\mathrm{O}^{2-}\right)$, hydroxyl radicals $\left(\mathrm{OH}^{-}\right)$, hydrogen peroxide $\left(\mathrm{H}_{2} \mathrm{O}_{2}\right)$, and other oxidant substances (Appel and Hirt, 2004). In order to achieve balance between the production and scavenging of ROS, plants activate their defense systems, which include enzymatic and non-enzymatic systems. Plants have ability to synthesize a wide range of antioxidants that can contribute the strengthening of the defense system of the plant, and some of these substances are phenolic compounds. The protection activity of phenolic compounds is achieved mainly due to their redox potential, which allowed them to act as scavenger of free radicals (Atmani et al., 2009).

The results of this study showed that the total antioxidant capacity (FRAP), total phenolic (TPC) and total flavonoid content (TFC) were significantly higher in leaves of cherry tomato seedlings exposed to drought stress than in non-stressed seedlings (Table 2), suggesting that plant initiates the intensive synthesis of phenolic compounds as a response to drought stress, and this hypothesis has been confirmed by many scientists (Basu et al., 2010; Cramer et al., 2011). 
Table 2: Total phenolic (TPC), total flavonoid content (TFC) and antioxidant capacity (FRAP) in leaves of cherry tomato seedlings

\begin{tabular}{lccc}
\hline Treatment & $\begin{array}{c}\text { FRAP } \\
\left(\mu \mathrm{mol} \mathrm{Fe} \mathrm{g}^{2+} \mathrm{DM}\right)\end{array}$ & $\begin{array}{c}\text { TPC } \\
\left(\mathrm{mg} \mathrm{g}^{-1} \mathrm{DM}\right)\end{array}$ & $\begin{array}{c}\text { TFC } \\
\left(\mathrm{mg} \mathrm{g}^{-1} \mathrm{DM}\right)\end{array}$ \\
\hline $\mathrm{V}_{1}$ ANE (stress) & $140.03 \pm 5.78^{\mathrm{a}}$ & $8.06 \pm 0,44^{\mathrm{a}}$ & $4.08 \pm 0.23^{\mathrm{a}}$ \\
\hline $\mathrm{V}_{2}$ ANE (non-stress) & $123.68 \pm 3.29^{\mathrm{c}}$ & $7.13 \pm 0,22^{\mathrm{b}}$ & $3.74 \pm 0.19^{\mathrm{bc}}$ \\
\hline $\mathrm{V}_{3}$ Non-treated (stress) & $133.93 \pm 5.63^{\mathrm{b}}$ & $7.07 \pm 0,06^{\mathrm{bc}}$ & $3.86 \pm 0.09^{\mathrm{b}}$ \\
\hline $\mathrm{V}_{4}$ Non-treated (non-stress) & $102.87 \pm 1.68^{\mathrm{d}}$ & $5.99 \pm 0,22^{\mathrm{d}}$ & $2.88 \pm 0.09^{\mathrm{d}}$ \\
\hline LSD $_{0.05}$ & 5.70 & 0.427 & 0.127 \\
\hline
\end{tabular}

Values expressed as main \pm standard deviation.

Different letters in each column represent significant difference among variants at 0.05 level of probability

As shown in Table 2 cherry tomato seedlings treated by ANE have a higher content of phenolic and among them flavonoids in leaves of cherry tomato seedlings compared to non-treated seedlings, both in standard as well as stressful growth conditions. These effects can also be attributed to the specific chemical composition of ANE. It's well known that seaweed extracts contains amino acid phenylalanine, tyrosine and tryptophan which serve as precursor for the synthesis of a wide range of phenolic compounds, so it can be assumed that application of ANE promote the synthesis of phenolic compounds in cherry tomato plants.

\subsection{Yield and quality parameters of cherry tomato fruits}

In order to test how the exposure of cherry tomato seedlings to drought and application of ANE impact on the yield and quality parameters of cherry tomato fruits, the analysis of yield and quality parameters of fruit were carried out, and the results are shown in Table 3 and 4.

Table 3: Yield, total soluble solids (TSS), titratable acidity (TA) and vitamin C content of cherry tomato fruits

\begin{tabular}{lcccc}
\hline Treatment & $\begin{array}{c}\text { Yield } \\
(\text { kg per plant) }\end{array}$ & $\begin{array}{c}\text { TSS } \\
(\text { Brix })\end{array}$ & $\begin{array}{c}\text { TA } \\
(\%)\end{array}$ & $\begin{array}{c}\text { Vitamin C } \\
\left(\mathrm{mg} \mathrm{100} \mathrm{g}^{-1} \mathrm{FM}\right)\end{array}$ \\
\hline $\mathrm{V}_{1}$ ANE (stress) & $1.77 \pm 0.2^{\mathrm{bc}}$ & $6.59 \pm 0.13^{\mathrm{ab}}$ & $0.64 \pm 0.01^{\mathrm{b}}$ & $13.77 \pm 1.34$ \\
\hline $\mathrm{V}_{2}$ ANE (non-stress) & $2.41 \pm 0.25^{\mathrm{a}}$ & $6.54 \pm 0.09^{\mathrm{abc}}$ & $0.61 \pm 0.02^{\mathrm{c}}$ & $13.33 \pm 0.67$ \\
\hline $\mathrm{V}_{3}$ Non-treated (stress) & $1.07 \pm 0.8^{\mathrm{d}}$ & $6.66 \pm 0.13^{\mathrm{a}}$ & $0.66 \pm 0.02^{\mathrm{a}}$ & $13.66 \pm 0.66$ \\
\hline $\mathrm{V}_{4}$ Non-treated (non-stress) & $2.07 \pm 0.41^{\mathrm{ab}}$ & $6.34 \pm 0.12^{\mathrm{d}}$ & $0.62 \pm 0.01^{\mathrm{c}}$ & $13.22 \pm 1$ \\
\hline LSD $_{0.05}$ & 0.395 & 0.126 & 0.019 & - \\
\hline
\end{tabular}

Values expressed as main \pm standard deviation.

Different letters in each column represent significant difference among variants at 0.05 level of probability

Table 4: Lycopene, total phenolic content (TPC), total flavonoid content (TFC) and total antioxidant capacity (FRAP) of cherry tomato fruits

\begin{tabular}{lcccc}
\hline Variant & $\begin{array}{c}\text { Lycopene } \\
\left(\mu \mathrm{g} \mathrm{g}^{-1} \mathrm{FM}\right)\end{array}$ & $\begin{array}{c}\text { TPC } \\
\left(\mathrm{mg} \mathrm{g}^{-1} \mathrm{DM}\right)\end{array}$ & $\begin{array}{c}\text { TFC } \\
\left(\mathrm{mg} \mathrm{g}^{-1} \mathrm{DM}\right)\end{array}$ & $\begin{array}{c}\text { FRAP } \\
\left(\mu \mathrm{mol} \mathrm{Fe}^{2+} \mathrm{g}^{-1} \mathrm{DM}\right)\end{array}$ \\
\hline $\mathrm{V}_{1}$ ANE (stress) & $90.66 \pm 2.69^{\mathrm{a}}$ & $10.56 \pm 0.81^{\mathrm{a}}$ & $5.39 \pm 0.49^{\mathrm{a}}$ & $188.35 \pm 8.37^{\mathrm{ab}}$ \\
\hline $\mathrm{V}_{2}$ ANE (non-stress) & $88.25 \pm 2.97^{\mathrm{ab}}$ & $9.48 \pm 0.56^{\mathrm{c}}$ & $4.71 \pm 0.44^{\mathrm{c}}$ & $155.9 \pm 13.41^{\mathrm{c}}$ \\
\hline $\mathrm{V}_{3}$ Non-treated (stress) & $88.25 \pm 2.12^{\mathrm{ab}}$ & $10.44 \pm 1.06^{\mathrm{ab}}$ & $5.31 \pm 0.34^{\mathrm{ab}}$ & $194.26 \pm 10.82^{\mathrm{a}}$ \\
\hline $\mathrm{V}_{4}$ Non-treated (non-stress) & $86.17 \pm 3.11^{\mathrm{b}}$ & $8.55 \pm 0.37^{\mathrm{d}}$ & $4.26 \pm 0.12^{\mathrm{d}}$ & $141.43 \pm 4.90^{\mathrm{d}}$ \\
\hline $\mathrm{LSD}_{0.05}$ & 2.47 & 0.617 & 0.346 & 12.91 \\
\hline
\end{tabular}

Values expressed as main \pm standard deviation.

Different letters in each column represent significant difference among variants at 0.05 level of probability

As shown in Table 3, total soluble solids, titratable acidity and vitamin $\mathrm{C}$ of fruits were higher in plants exposed to stress as compared to non-stressed plants, regardless of ANE treatment, but for vitamin $\mathrm{C}$, that increase was not statistically justified. The total antioxidant capacity and the content of secondary metabolites such as lycopene, phenolic and flavonoids were also significantly higher in fruits of cherry tomato exposed to drought stress (Table 4). Besides, analyses of individual flavonoid compound indicate that the 
dominant flavonoid in fruits of cherry tomato tomato fruits as response to drought stress (Table 5). naringenin and rutin, also accumulates more in cherry

Table 5: Naringenin and rutin content of cherry tomato fruits

\begin{tabular}{|c|c|c|}
\hline Treatment & 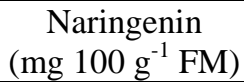 & $\begin{array}{c}\text { Rutin } \\
\left(\mathrm{mg} 100 \mathrm{~g}^{-1} \mathrm{FM}\right)\end{array}$ \\
\hline $\mathrm{V}_{1}$ ANE (stress) & $3.87 \pm 0.36^{\mathrm{a}}$ & $6.62 \pm 0.19^{b}$ \\
\hline $\mathrm{V}_{2}$ ANE (non-stress) & $3.01 \pm 0.21^{\mathrm{bc}}$ & $5.64 \pm 0.08^{c}$ \\
\hline $\mathrm{V}_{3}$ Non-treated (stress) & $3.29 \pm 1.03^{\mathrm{b}}$ & $7.55 \pm 0.07^{\mathrm{a}}$ \\
\hline $\mathrm{V}_{4}$ Non-treated (non-stress) & $2.89 \pm 0.14^{\mathrm{c}}$ & $5.71 \pm 0.63^{\mathrm{c}}$ \\
\hline $\mathrm{LSD}_{0.05}$ & 0.306 & 0.217 \\
\hline
\end{tabular}

Values expressed as main \pm standard deviation.

Different letters in each column represent significant difference among variants at 0.05 level of probability

These results indicate that the contents of antioxidants in plant are closely related to the growth conditions and that their content in plant increases if the plant is exposed to controlled drought stress conditions. Many studies have shown the similar effect of drought stress on the content of antioxidant substances and generally secondary metabolites in tomato fruits (Atkinson et al., 2011; Giannakoula and Ilias, 2013). There is therefore no doubt that higher production of secondary metabolites is one of basic response of plant to controlled drought stress and conclusions of many studies support this hypothesis (Murshed et al., 2013; Okunlola et al., 2015). These observations are very interesting in terms of improving cherry tomato quality since that vegetable containing phytochemicals with high antioxidant power are drawing increased interest from consumers (Kubota et al., 2006).

The negative impact of drought stress on cherry tomato fruits in the present study was related to the yield, that was significantly lower in stressed plants, what was expected since the lack of water causes losses in tissue water content which reduce turgor pressure in cell, thereby inhibiting enlargement and division of cell, causing of reduce of yield. However, in experiment where cherry tomato seedlings were treated by ANE before exposure to stress, the yield was significantly higher compared to non-treated plants exposed to stress, indicating that this fertilizer reduces negative effects of drought on yield.

Furthermore, treatment of cherry tomato seedlings with ANE, has significantly contributed to increase the content of phenolic and flavonoids in fruits of cherry tomato under standard (non-stress) growth conditions, confirming that this fertilizer stimulate the synthesis of phenolic compounds, and thereby strengthen antioxidant defense mechanism of the plant. This fertilizer was also positively influenced by some quality parameters of cherry tomato (total soluble solids, content of ascorbic acid and lycopene) under standard growth conditions (non-stress) as compared to untreated plants.

\section{CONCLUSIONS}

ANE application in cherry tomato cultivation contributes to better adaptation of seedlings to drought conditions. The application of ANE also positively influenced by the yield and quality of cherry tomato under both standard and drought stress conditions as compared to untreated plants in same conditions. Positive effects of application of ANE are result of its specific composition, as well as ability of cherry tomato plants to utilize bioactive substances in seaweed extracts for its growth and development. The results of this study also indicate that the controlled exposure of cherry tomato plants to drought stress improves fruit quality, increasing nutritional components but decreasing yield.

\section{REFERENCES}

Aldana, F, García, P. N., Fischer, G. (2014). Effect of waterlogging stress on the growth, development and symptomatology of cape gooseberry (Physalis peruviana L.) plants. Revista de la Academia Colombiana de Ciencias Exactas, Físicas y
Naturales, $\quad 38(149)$,

doi:10.18257/raccefyn. 114 
Effects of seaweed extract on the growth, yield and quality of cherry tomato under different growth conditions

Ali, N., \& Anjum, M. M. (2016). Drought Stress: Major cause of low yield and productivity. Austin Environmental Sciences, 1(3), 1012.

Ali, N., Farrell, A., Ramsubhag, A., \& Jayaraman, J. (2016). The effect of Ascophyllum nodosum extract on the growth, yield and fruit quality of tomato grown under tropical conditions. Journal of applied phycology, 28(2), 1353-1362. doi:10.1007/s10811015-0608-3

Anjum, S. A., Xie, X., Wang, L., Saleem, M. F., Man, C., Lei, W. (2011). Morphological, physiological and biochemical responses of plants to drought stress. African Journal of Agricultural Research, 6(9), 2026-2032.

AOAC, (2000). Acidity (Titratable) of fruit products (Method No. 942.15). Official Methods of Analysis, $17^{\text {th }}$ Ed. AOAC International, Washington.

AOAC, (2006). Vitamin $C$ in juices and vitamin preparations (Method No. 967.21). Official Methods of Analysis, $18^{\text {th }} \mathrm{Ed}$. AOAC International, Arlington.

Appel, K., \& Hirt, H. (2004). Reactive oxygen species: metabolism, oxidative stress, and signal transduction. Annual Review of Plant Biology, 55, 373-399.

doi:10.1146/annurev.arplant.55.031903.141701

Arioli, T., Mattner, S. W., Winberg. P. C. (2015). Applications of seaweed extracts in Australian agriculture: past, present and future. Journal of Applied Phycology, 27(5), 2007-2015. doi:10.1007/s10811-015-0574-9

Atkinson, N. J., Dew, T. P., Orfila, C., Urwin, P. E. (2011). Influence of combined biotic and abiotic stress on nutritional quality parameters in tomato (Solanum lycopersicum). Journal of Agricultural and Food Chemistry, 59(17), 9673-9682. doi:10.1021/jf202081t

Atkinson, N. J., \& Urwin, P. E. (2012). The interaction of plant biotic and abiotic stresses: from genes to the field. Journal of Experimental Botany, 63(10), 3523-3543. doi:10.1093/jxb/ers100

Atmani, D., Chaher, N., Berboucha, M., Ayouni, K., Lounis, H., Boudaoud, H., Debbache, N., Atmani, D. (2009). Antioxidant capacity and phenol content of selected Algerian medicinal plants. Food Chemistry, 112(2), 303-309. doi:10.1016/j.foodchem.2008.05.077

Basu, S., Roychoudhury, A., Saha, P. P., Sengupta, D. N. (2010). Differential antioxidative responses of Indica rice cultivars to drought stress. Plant Growth
Regulation, 60, 51-59. doi:10.1007/s10725-0099418-4

Bates, L. S., Waldren, R. P., Teare, I. D. (1973). Rapid determination of free proline for water-stress studies. Plant and Soil, 39(1), 205-207. doi:10.1007/BF00018060

Benzie, I. F., \& Strain, J. J. (1996). Ferric reducing ability of plasma (FRAP) as a measure of antioxidant power: The FRAP assay. Analytical Biochemistry, 239, 70-76. doi:10.1006/abio.1996.0292

Craigie, J. S. (2011). Seaweed extract stimuli in plant science and agriculture. Journal of Applied Phycology, 23(3), 371-393. doi:10.1007/s10811010-9560-4

Cramer, G. R., Urano, K., Delrot, S., Pezzotti, M., Shinozaki, K. (2011). Effects of abiotic stress on plants: a systems biology perspective. BMC Plant Biology, 11, 163. doi:10.1186/1471-2229-11-163

Davis, A. R., Fish, W. W., Perkins-Veazie, P. (2003). A rapid spectrophotometric method for analyzing lycopene content in tomato and tomato products. Postharvest Biology and Technology, 28(3), 425430. doi:10.1016/S0925-5214(02)00203-X

Dobromilska, R., Mikiciuk, M., Gubarewicz, K. (2008). Evaluation of cherry tomato yielding and fruit mineral composition after using of Bio algeen S-90 preparation. Journal of Elementology, 13(4), 491499.

Escarpa, A., \& Gonzalez, M. C. (2000). Optimization strategy and validation of one chromatographic method as approach to determine the phenolic compounds from different sources. Journal of Chromatography A, 897, 161-70. doi:10.1016/S0021-9673(00)00817-7

Galmés, J., Ochogavía, J. M., Gago, J., Roldán, E. J., Cifre, J., Conesa, M. A. (2013). Leaf responses to drought stress in Mediterranean accessions of Solanum lycopersicum: anatomical adaptations in relation to gas exchange parameters. Plant Cell \& Environment, 36(5), 920-935.

Ghorbanli, M., Gafarabad, M., Amirkian, T., Mamaghani, B. A. (2013). Investigation on proline, total protein, chlorophyll ascorbate and dehydroascorbate changes under drought stress in Akria and Mobil tomato cultivars. Iranian Journal of Plant Physiology, 3(2), 651-658.

Giannakoula, A. E., \& Ilias, I. F. (2013). The effect of water stress and salinity on growth and physiology of tomato. Archives of Biological Science Belgrade, 65(2), 611-620. 
González, A., Castro, J., Vera, J., Moenne, A. (2013). Seaweed oligosaccharides stimulate plant growth by enhancing carbon and nitrogen assimilation, basal metabolism, and cell division. Journal of Plant Growth Regulation, 32(2), 443-448. doi:10.1007/s00344-012-9309-1

Ha, C. V., Leyva-González, M. A., Osakabe, Y., Tran, U. T., Nishiyama, R., Watanabe, Y., ... Tran, L. S. P. (2014). Positive regulatory role of strigolactone in plant responses to drought and salt stress. Proceedings of the National Academy of Sciences, 111(2), doi:10.1073/pnas.1322135111

851-856.

Hayat, S., Hayat, Q., Alyemeni, M. N., Wani, A. S., Pichtel, J., Ahmad, A. (2012). Role of the proline under changing environments. Plant Signaling \& Behavior, 7(11), 1456-1466. doi:10.4161/psb.21949

ISO, (2003). Fruit and vegetable productsDetermination of soluble solids, Refractometric method. ISO 2173, International Organization for Standardization, Geneva, Switzerland.

Jaleel, C. A., Manivannan, P., Wahid, A., Farooq, M., Al-Juburi, H. J., Somasundaram, R., Vam, R. P. (2009). Drought stress in plants: A review on morphological characteristics and pigments composition. International Journal of Agriculture \& Biology, 11, 100-105.

Jureková, Z., Németh-Molnár, K., Paganová, V. (2011). Physiological responses of six tomato (Lycopersicon esculentum Mill.) cultivars to water stress. Journal of Horticulture and Forestry, 3(10), 294-300.

Karabudak, T., Bor, M., Özdemir, F., Türkan. I. (2014). Glycine betaine protects tomato (Solanum lycopersicum) plants at low temperature by inducing fatty acid desaturase7 and lipoxygenase gene expression. Molecular Biology Reports, 41(3), 1401-1410. doi:10.1007/s11033-013-2984-6

Khan, W., Rayirath, U. P., Subramanian, S., Jithesh, M. N., Rayorath, P., Hodges, D. M., Critchley, A. T., Craigie, J. S., Norrie, J., Prithiviraj, B. (2009). Seaweed extracts as biostimulants of plant growth and development. Journal of Plant Growth Regulation, 28(4), 386-399. doi:10.1007/s00344009-9103-X

Knipling, E. B. (1967). Measurement of leaf water potential by the dye method. Ecology, 48(6), 10381041.

Kubota, C., Thomson, C., Wu, M., Javanmardi, J. (2006). Controlled environments for production of value-added food crops with high phytochemical concentrations: Lycopene in tomato as an example. HortScience, 41(3), 522-525.

Li, Y., \& Mattson, N. S. (2015). Effect of seaweed extract application rate and method on postproduction life of petunia and tomato transplants. HortTechnology, 25(4), 505-510.

Lichtenthaler, H. K., \& Wellburn, W. R. (1983). Determination of total carotenoids and chlorophylls $a$ and $b$ of leaf extracts in different solvents. Biochemical Society Transactions, 11(5), 591-592. doi:10.1042/bst0110591

Marks, S. C., Mullen, W., Croizer, A. (2007). Flavonoid and chlorogenic acid profiles of English cider apples. Journal of the Science of Food and Agriculture, 87, 719-728. doi:10.1002/jsfa.2778

Mikiciuk, M., \& Dobromilska, R. (2014). Assessment of yield and physiological indices of small-sized tomato cv.'Bianka F1'under the influence of biostimulators of marine algae origin. Acta Scientiarum Polonorum-Hortorum Cultus, 13(1), 31-41.

Murshed, R., Lopez-Lauri, F, Sallanon, H. (2013). Effect of water stress on antioxidant systems and oxidative parameters in fruits of tomato (Solanum lycopersicon L, cv. Micro-tom). Physiology and Molecular Biology of Plants, 19(3), 363-378. doi:10.1007/s12298-013-0173-7

Neily, W., Shishkov, L., Nickerson, S., Titus, D., Norrie, J. (2010). Commercial extracts from the brown seaweed Ascophyllum nodosum (Acadian ${ }^{\circledR}$ ) improves early establishment and helps resist water stress in vegetable and flower seedlings. HortScience 45, S234.

Nuruddin, M. M., Madramootoo, C. A., Dodds, G. T. (2003). Effects of water stress at different growth stages on greenhouse tomato yield and quality. HortScience, 38(7), 1389-1393.

Okunlola, G. O., Adelusi, A. A., Olowolaju, E. D., Oseni, O. M., Akingboye, G. L. (2015). Effect of water stress on the growth and some yield parameters of Solanum lycopersicum L. International Journal of Biological and Chemical Sciences, 9(4), 1755-1761. doi:10.4314/ijbcs.v9i4.2

Ough, C. S., \& Amerine, M. A. (1988). Phenolic compounds. In Methods for analysis of must and wines (pp. 50-70). New York: Wiley.

Pandey, S. K., \& Singh, H. 2011. A simple, costeffective method for leaf area estimation. Journal of Botany, 658240, 6. doi:10.1155/2011/658240 
Sanchez-Rodriguez, E., Moreno, D. A., Ferreres, F., Rubio-Wilhelmi, M., Ruiz, J. M. (2011). Differential responses of five cherry tomato varieties to water stress: changes on phenolic metabolites and related enzymes. Phytochemistry, $72(8)$, 723-729. doi:10.1016/j.phytochem.2011.02.011

Spann, T. M, \& Little, H. A. (2011). Applications of a commercial extract of the brown seaweed Ascophyllum nodosum increases drought tolerance in container-grown 'Hamlin' sweet orange nursery trees. HortScience, 46(4), 577-582.

Tilman, D, Cassman, K. G., Matson, P. A., Naylor, R., Polasky, S. (2002). Agricultural sustainability and intensive production practices. Nature, 418(6898), 671-677. doi:10.1038/nature01014

Wettstein, D. (1957). Chlorophyll letale und der submikroskopische Formwechsel der Plastiden.
Experimental Cell Research, 12(3), 427-434. https://doi:10.1016/0014-4827(57)90165-9

Yuan, X. K., Yang, Z. Q., Li, Y. X, Liu, Q, Han, W. (2016). Effects of different levels of water stress on leaf photosynthetic characteristics and antioxidant enzyme activities of greenhouse tomato. Photosynthetica, 54, 28-39. doi:10.1007/s11099015-0122-5

Zhang, X., \& Ervin, E. H. (2004). Cytokinin-containing seaweed and humic acid extracts associated with creeping bentgrass leaf cytokinins and drought resistance. Crop Science, 44(5), 1737-1745. doi:10.2135/cropsci2004.1737

Zhishen, J, Mengcheng, T, Jianming, W. (1999). The determination of flavonoid contents in mulberry and their scavenging effects on superoxide radicals. Food Chemistry, 64(4), 555-559. doi:10.1016/S0308-8146(98)00102-2 